\title{
Identifikasi Barcode pada Gambar yang Ditangkap Kamera Digital Menggunakan Metode JST
}

\author{
Salman Aliaji ${ }^{* 1}$, Agus Harjoko ${ }^{2}$ \\ ${ }^{1}$ Program Studi S2/S3 Ilmu Komputer, FMIPA UGM \\ ${ }^{2}$ Jurusan Ilmu Komputer dan Elektronika, FMIPA UGM \\ Gedung SIC Lt.3 FMIPA UGM Sekip Utara Bulaksumur Yogyakarta \\ e-mail: *11 haiii.ajik@gmail.com, ${ }^{2}$ aharjoko@ugm.ac.id
}

\begin{abstract}
Abstrak
Dewasa ini hampir setiap produk konsumen memiliki label barcode. Namun alat pembaca barcode jenis laser memiliki kelemahan karena tidak dapat mengenali barcode yang mengalami goresan atau noise. Namun telah dikembangkan teknik lain dengan memanfaatkan kamera digital untuk identifikasi barcode. JST telah banyak digunakan untuk identifikasi berbagai macam pola. Proses identifikasi barcode dalam JST terdiri dari proses training dan proses identifikasi. Proses training menggunakan metode LVQ (Learning Vector Quantization). Proses identifikasi terdiri dari beberapa tahap, yaitu akuisisi citra, preprocessing, locating barcode, proses pengujian dan verifikasi. Berdasarkan hasil pengujian metode LVQ dapat digunakan untuk identifikasi foto barcode dengan kinerja yang baik. Hasil pengujian menunjukkan tingkat akurasi sebesar 73,6 \% dari 72 citra yang diuji dengan waktu rata-rata adalah 0.5 detik. Sementara waktu yang dibutuhkan untuk menemukan lokasi barcode adalah sekitar 6 detik menggunakan blok dengan ukuran $32 \times 32$ pixel.
\end{abstract}

Kata kunci-Barcode, Learning Vector Quantization, Jaringan Syaraf Tiruan

\begin{abstract}
Abstrak
In today's modern society, almost every consumer product has a barcode label. But the barcode reader with laser type has the disadvantage of not being able to recognize the barcode has a scratch or noise. However, other techniques have been developed by using a digital camera for barcode identification. ANN has been widely used for identification of various patterns. Barcode identification process consists of the ANN training process and the identification process. Training process using the LVQ (Learning Vector Quantization). Identification process consists of several stages: image acquisition, preprocessing, locating barcode, testing and verification process. Based on test results LVQ method can be used for photo identification barcode with good performance. The test results showed an accuracy of $73.6 \%$ rate of 72 images were tested with an average time is 0.5 seconds. While the time required to find the location of the barcode is about 6 seconds using a block size of $32 \times 32$ pixels.
\end{abstract}

Keyword - Barcode, Learning Vector Quantization, Artificial Neural Network

\section{PENDAHULUAN}

$\mathrm{D}$ alam masyarakat modern saat ini, hampir setiap produk konsumen memiliki label barcode. Dengan menggunakan barcode scanner laser, informasi tentang sebuah produk seperti deskripsi dan harga dapat dengan cepat diperoleh. Konsumen juga dapat menangkap gambar label barcode menggunakan ponsel kamera mereka. Dengan menghubungkan secara online, konsumen kemudian dapat mendapatkan akses ke banyak informasi tentang produk. Ini 
termasuk tidak hanya deskripsi produk dan harga tetapi juga review produk, perbandingan harga, lokasi penjualan, dan lain-lain.

Teknologi pembaca barcode (barcode scanner) pada saat ini telah mengalami kemajuan yang pesat, tapi yang paling populer dan banyak dijumpai adalah yang menggunakan sinar laser. Kelemahan barcode scanner laser adalah tidak bisa digunakan untuk membaca barcode 2 dimensi [1]. Menurut [2], bahwa ada beberapa kelemahan dalam jenis-jenis pembaca barcode, kerugian ini termasuk bahwa barcode harus secara manual berorientasi pada sinar laser untuk mendapatkan nilai barcode, biaya tinggi dan berbahaya bagi pengguna dari paparan sinar laser. Selain itu, kelemahan lainnya menurut Ezekiel dkk, barcode scanner hanya bekerja jika gambar barcode dikenali. Jika terjadi distorsi gambar maka akan gagal untuk mengenali karakter [3]. Tidak jarang pula ditemukan label barcode yang dicetak pada bidang yang melengkung dan mengalami goresan, kabur atau rusak.

Selain teknologi pembaca barcode menggunakan sinar laser tersebut, telah dikembangkan juga teknik lain menggunakan pengolahan citra digital. Salah satu aplikasinya menggunakan kamera cerdas untuk identifikasi barcode, dimana gambar digital diproses oleh mikroprosesor untuk memperoleh data yang dikodekan dalam barcode. Namun, pengolahan gambar barcode memiliki banyak tantangan karena gambar dapat kabur, miring, atau terdistorsi [4]. Menurut [5], bahwa metode berbasis kamera umumnya menghasilkan scanlines dengan kualitas jauh lebih rendah. Selain itu, label barcode umumnya tidak sepenuhnya mengisi foto, oleh karena itu langkah pertama untuk interpretasi barcode adalah menemukan lokasinya [5].

Penggunaan jaringan syaraf tiruan memungkinkan akan memberikan hasil optimal, karena memiliki kelebihan dalam menyelesaikan persoalan yang sifatnya non-linear. Salah satu kelebihan dari jaringan syaraf ini adalah kemampuannya untuk belajar melalui suatu algoritma pembelajaran. Setelah melalui proses pembelajaran maka jaringan syaraf tiruan ini dapat digunakan untuk melakukan prediksi, atau memberi alternatif output. Salah satu contoh metode jaringan syaraf tiruan (neural network) adalah metode Learning Vector Quantization (LVQ). LVQ adalah jaringan saraf yang menggabungkan pembelajaran kompetitif dengan pengawasan. Hal ini dapat digunakan untuk klasifikasi pola [6]. Karena kesederhanaan, fleksibilitas, dan efisiensi, metode LVQ yang telah diperkenalkan oleh Kohonen telah banyak digunakan dalam berbagai bidang, termasuk aplikasi real time seperti pengenalan suara [7].

Dalam penelitian sebelumnya terdapat beberapa penelitian sejenis yang telah dilakukan untuk identifikasi barcode berbasis kamera. Chai dan Hock melakukan operasi morfologi untuk menemukan label barcode di dalam gambar terlebih dahulu sebelum melakukan identifikasi [8]. Berdasarkan percobaan kami metode locating barcode yang mereka usulkan memiliki kelemahan karena gambar yang dihasilkan masih memiliki derau yang cukup tinggi. Pendekatan lain yang digunakan oleh [9], adalah mengasumsikan bahwa label barcode berada di tengah gambar. Hal tersebut sangat menyederhanakan masalah karena label barcode tidak selaku ada di tengah-tengah gambar. Berdasarkan tulisannya Wachenfeld, dkk melaporkan tingkat akurasi yang cukup mengesankan namun sayangnya mereka tidak melakukan uji komparatif terhadap metode lainnya. Penelitian lain dilakukan oleh [10], yang mengusulkan kerangka kerja Bayesian elegan untuk barcode decoding. Dalam proses pengujiannya mereka mengasumsikan bahwa label barcode yang diidentifikasi telah dilakuka proses segmentasi terlebih dahulu.

\subsection{EAN-13 (European Article Numbering)}

EAN adalah singkatan European Article Numbering. Barcode EAN-13 telah digunakan di seluruh dunia untuk menandai barang eceran. Barcode ini memiliki 13 karakter numerik yang juga dikenal sebagai digit. Dua atau tiga karakter pertama adalah kode negara, kemudian diikuti dengan 11 atau 10 karakter (tergantung pada panjang kode negara) untuk kode produsen dan kode produk. Karakter ke 13 barcode EAN-13 adalah digit checksum. Bagian-bagian dari sistem barcode EAN-13 ditunjukkan pada Gambar 1.

IJCCS Vol. 7, No. 2, July 2013 : $121-132$ 


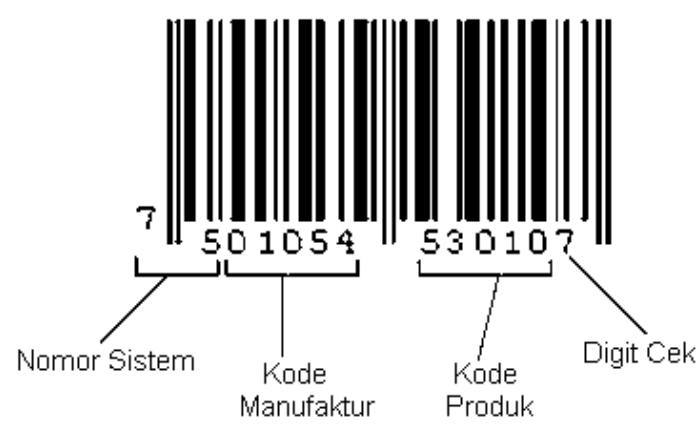

Gambar 1 Bagian-bagian dari sistem barcode EAN-13

Aturan pengkodean EAN-13 terdiri dari 3 jenis pola. Hal ini dapat disebut sebagai pola A, B, dan C. Masing-masing karakter dari pola A, B, dan C memiliki pola yang berbeda. Misalkan pada karakter angka 2 dari pola A terdiri dari: 0010011 sedangkan angka 2 dalam pola B terdiri dari: 0011011. Pola Karakter A,B dan C pada Barcode EAN-13 ditunjukkan pada Tabel 1.

Tabel 1 Pola Karakter A,B dan C pada Barcode EAN-13 [11]

\begin{tabular}{|c|c|c|c|}
\hline Digit & Tipe A & Tipe B & Tipe C \\
\hline 0 & 0001101 & 0100111 & 1110010 \\
\hline 1 & 0011001 & 0110011 & 1100110 \\
\hline 2 & 0010011 & 0011011 & 1101100 \\
\hline 3 & 0111101 & 0100001 & 1000010 \\
\hline 4 & 0100011 & 0011101 & 1011100 \\
\hline 5 & 0110001 & 0111001 & 1001110 \\
\hline 6 & 0101111 & 0000101 & 1010000 \\
\hline 7 & 0111011 & 0010001 & 1000100 \\
\hline 8 & 0110111 & 0001001 & 1001000 \\
\hline 9 & 0001011 & 0010111 & 1110100 \\
\hline
\end{tabular}

Pola A dan B digunakan untuk karakter kode manufaktur dan digit kedua dari nomor sistem yang merupakan left hand side. Sedangkan pola C digunakan untuk karakter pada kode produk dan digit cek yang merupakan right hand side. Aturan penggunaan pola A atau pola B yang ditentukan oleh digit pertama dari nomor sistem ditunjukkan pada Tabel 2.

Tabel 2 Aturan Pengkodean Left Hand Side pada Barcode EAN-13 [11]

\begin{tabular}{|c|c|c|c|c|c|c|}
\hline Digit ke-1 & \multicolumn{7}{|c|}{ Aturan Pengkodean Untuk Left Hand Side } \\
\hline 0 & A & A & A & A & A & A \\
\hline 1 & A & A & B & A & B & B \\
\hline 2 & A & A & B & B & A & B \\
\hline 3 & A & A & B & B & B & A \\
\hline 4 & A & B & A & A & B & B \\
\hline 5 & A & B & B & A & A & B \\
\hline 6 & A & B & B & B & A & A \\
\hline 7 & A & B & A & B & A & B \\
\hline 8 & A & B & A & B & B & A \\
\hline 9 & A & B & B & A & B & A \\
\hline
\end{tabular}

\subsection{Learning Vector Quantization (LVQ)}

Learning Vector Quantization (LVQ) adalah suatu metode neural network untuk melakukan pembelajaran pada lapisan kompetitif yang terawasi. Suatu lapisan kompetitif akan secara otomatis belajar untuk mengklasifikasikan vektor-vektor input. Kelas-kelas yang 
didapatkan sebagai hasil dari lapisan kompetitif ini hanya tergantung pada jarak antara vektorvektor input. Jika 2 vektor input mendekati sama, maka lapisan kompetitif akan meletakkan kedua vektor input tersebut ke dalam kelas yang sama [6]. Arsitektur metode LVQ ditunjukkan pada Gambar 2.

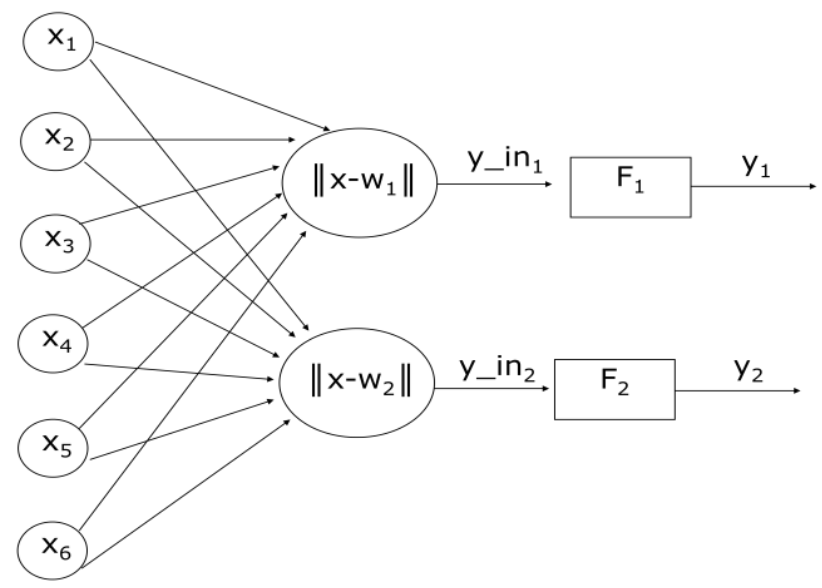

Gambar 2 Arsitektur jaringan LVQ

Gambar 2 adalah arsitektur jaringan LVQ yang terdiri dari 6 node lapisan masukan (input layer), 2 node lapisan tersembunyi (hidden layer) serta 2 node lapisan keluaran (output layer). Lapisan input memiliki 6 node yang disimbolkan dengan nilai $\mathrm{x}_{1}, \mathrm{x}_{2}, \mathrm{x}_{3}, \mathrm{x}_{4}, \mathrm{x}_{5}$ dan $\mathrm{x}_{6}$. Pada tiap lapis masukan terlebih dahulu diberikan dua nilai bobot yang berbeda yaitu $\mathrm{w}_{1}$ dan $\mathrm{w}_{2}$. Sehingga jaringan memiliki dua buah kelas yang berbeda, yaitu kelas 1 dan kelas 2 . Kelas 1 memiliki bobot $\mathrm{w}_{1}$ dan kelas 2 memiliki bobot $\mathrm{w}_{2}$. Keluaran dari lapisan ini akan menjadi masukan bagi lapisan tersembunyi (hidden layer) sebanyak 2 node yaitu $\mathrm{Y}_{\text {-in1 }}$ dan $\mathrm{Y}_{\text {_in2. }}$. Sedangkan F1 dan F2 merupakan fungsi pembanding. Algoritma pelatihan Jaringan Syaraf Tiruan dengan metode LVQ ini adalah sebagai berikut:

1. Tetapkan bobot (W), Maksimum epoch (MaxEpoch), error minimum yang diharapkan (Eps), learning rate $(\alpha)$

2. Masukkan:

- Input : $\mathrm{X}(\mathrm{m}, \mathrm{n})$

- Target : $\mathrm{T}(1, \mathrm{n})$

3. Tetapkan kondisi awal

- Epoch = 0

4. Kerjakan jika: (epoch $<$ MaxEpoch) atau $(\alpha>$ Eps)

a. $\quad$ Epoch $=$ Epoch +1

b. Kerjakan untuk $\mathrm{i}=1$ sampai $n$

i. Tentukan J sedemikian hingga $\|\mathrm{X}-\mathrm{Wj}\|$ minimum $(\mathrm{Cj})$

ii. Perbaiki Wj dengan ketentuan:

- $\quad$ Jika $\mathrm{T}=\mathrm{Cj}$ maka: $\mathrm{Wj}($ baru $)=\mathrm{Wj}($ lama $)+\alpha(\mathrm{X}-\mathrm{Wj}$ (lama)

- $\quad$ Jika $\mathrm{T} \neq \mathrm{Cj}$ maka: $\mathrm{Wj}($ baru $)=\mathrm{Wj}($ lama $)-\alpha(\mathrm{X}-\mathrm{Wj}(\mathrm{lama}))$

c. Kurangi nilai $\alpha$

\section{METODE PENELITIAN}

\subsection{Proses training}

Proses training adalah proses yang dilakukan untuk melakukan pembelajaran terhadap data input yang diberikan. Setiap data input dihitung nilai bobotnya dengan aturan perhitungan pada proses pembelajaran dengan metode LVQ (Learning Vector Quantization). Proses training terdiri dari beberapa proses antara lain input data pelatihan, pembuatan matrik, kemudian 
melakukan pembelajaran menggunakan metode LVQ. Proses training bertujuan untuk mengklasifikasikan vektor-vektor input kedalam kelas-kelas yang telah ditentukan sebelumnya. Dalam proses training tidak dilakukan pengolahan citra karena telah diketahui bentuk dari polapola penyusun barcode. Pola-pola yang telah diketahui tersebut kemudian dimanfaatkan sebagai data pelatihan (training set). Diagram alir proses training dalam penelitian ini ditunjukkan pada Gambar 3.

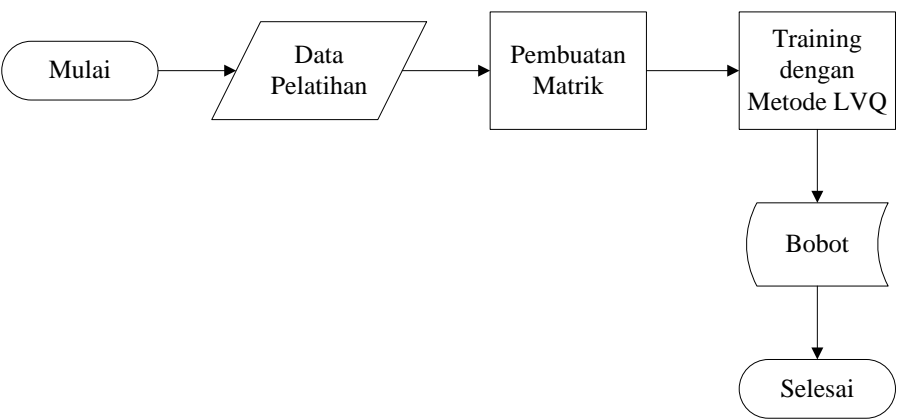

Gambar 3 Diagram alir proses training

\subsection{Proses identifikasi}

Proses identifikasi adalah proses untuk mengolah foto label barcode yang diberikan oleh user menjadi digit-digit angka nilai barcode. Proses identifikasi terdiri dari serangkaian proses yang saling mendukung dan memanfaatkan file bobot yang telah dihasilkan dalam proses training. Dalam proses identifikasi digunakan juga metode LVQ untuk melakukan pengujian terhadap pola dari citra yang sedang diproses. Dengan kata lain proses identifikasi adalah serangkaian proses yang digunakan untuk mengolah data input berupa citra label barcode menjadi digit nilai barcode. Proses ini terdiri dari proses akuisisi citra, preprocessing, locating barcode, scanline, normalisasi, identifikasi (pengujian) barcode menggunakan metode LVQ dan proses verifikasi. Proses locating barcode digunakan untuk menemukan label barcode dalam citra yang diberikan untuk diolah pada proses selanjutnya. Diagram alir dari proses identifikasi ditunjukkan melalui Gambar 4.
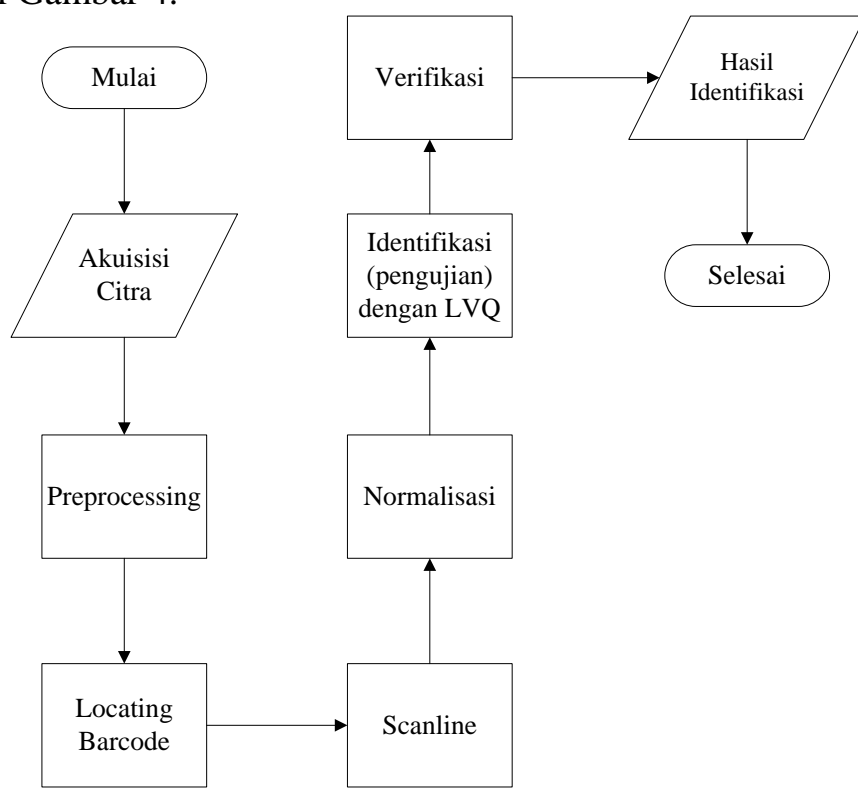

Gambar 4 Diagram alir proses identifikasi 


\subsubsection{Akuisisi citra}

Akuisisi citra merupakan langkah awal dari proses identifikasi barcode menggunakan metode LVQ yang dibuat dalam perancangan sistem. Untuk memperoleh citra label barcode dilakukan pengambilan gambar menggunakan kamera digital. Pengambilan gambar dengan kamera digital jenis Olympus FE-210 7.1 MP. Teknik pengambilan gambar dilakukan dengan cara memotret label barcode yang ingin diambil secara manual dengan jarak antara $8-20 \mathrm{~cm}$ sesuai dengan fokus yang diperoleh secara tegak lurus. Digunakan juga fungsi macro untuk mengambil gambar dari jarak yang sangat dekat. Resolusi gambar yang di-setting pada kamera menggunakan ukuran 640x480 piksel agar menghasilkan ukuran file yang kecil. Citra yang dihasilkan dalam proses ini memiliki komponen RGB dengan format "JPEG".

Permasalahan yang muncul dalam proses akuisisi citra ini adalah gambar yang diperoleh tidak selalu bagus. Gambar barcode hasil tangkapan kamera tersebut bisa menghasilkan citra yang kabur (tidak fokus), derau (terdapat bagian-bagian yang tidak dibutuhkan tertangkap oleh kamera), miring (karena peletakan objek tidak segaris dengan kamera), blurring dan masih banyak kekurangan lainnya. Hal ini tentu saja sangat berpengaruh dalam proses identifikasi. Beberapa contoh gambar label barcode yang berhasil diambil dapat dilihat pada Gambar 5.
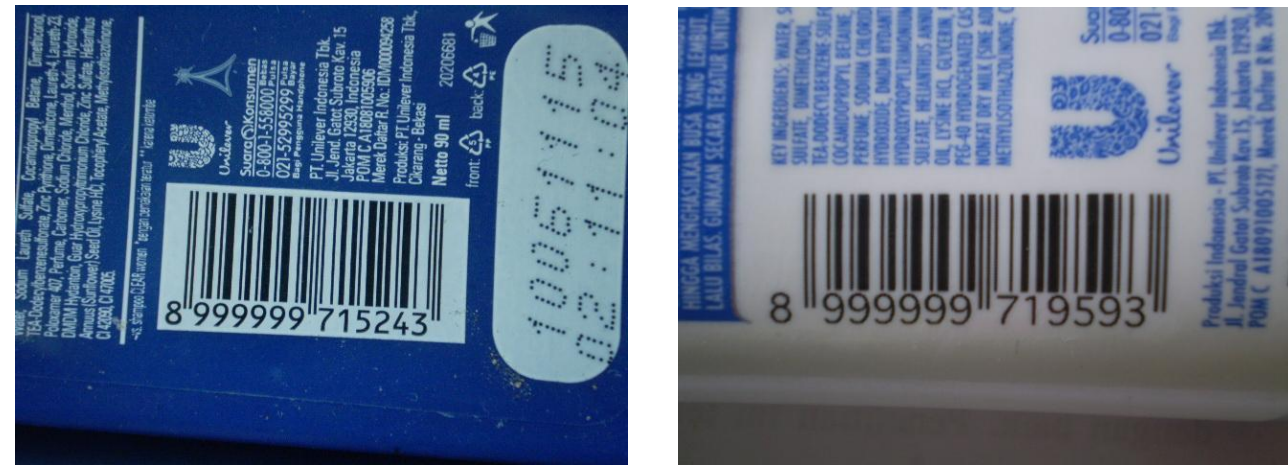

Gambar 5 Contoh gambar label barcode

\subsubsection{Preprocessing}

Pada tahap ini data citra masukan akan diubah menjadi data citra yang lebih sesuai untuk diproses. Preprocessing yang dilakukan meliputi beberapa tahap mulai dari input data citra, konversi RGB ke grayscale, dan resize sehingga menghasilkan citra sesuai dengan standar yang diharapkan dan dapat memudahkan proses selanjutnya.

\subsubsection{Locating barcode}

Proses locating barcode bertujuan untuk menemukan lokasi label barcode yang sesungguhnya. Gambar label barcode yang tertangkap oleh kamera digital umumnya tidak sepenuhnya mengisi foto, namun dalam foto tersebut tertangkap juga sebagian besar gambar produk dimana label barcode tersebut menempel. Bagian-bagian dalam citra selain gambar label barcode tersebut merupakan pengganggu (derau) yang tidak dibutuhkan dalam proses identifikasi.

Derau dalam data citra tersebut perlu dihilangkan, namun karena kondisi gambar yang berbeda-beda mengakibatkan proses ini menjadi sulit untuk dilakukan. Selain itu label barcode pun memiliki warna dan ukuran-ukuran yang berbeda menyesuaikan dengan produknya, sehingga analisis citra yang dipakai untuk menghilangkan derau pada suatu citra tidak bisa diterapkan untuk citra lainnya. Proses locating barcode merupakan rangkaian proses untuk menemukan lokasi label barcode sehingga dapat mengurangi derau yang ada. Kegagalan dalam proses ini menyebabkan sistem tidak dapat melakukan proses selanjutnya. Diagram alir dari proses locating barcode ditunjukkan pada Gambar 6. 


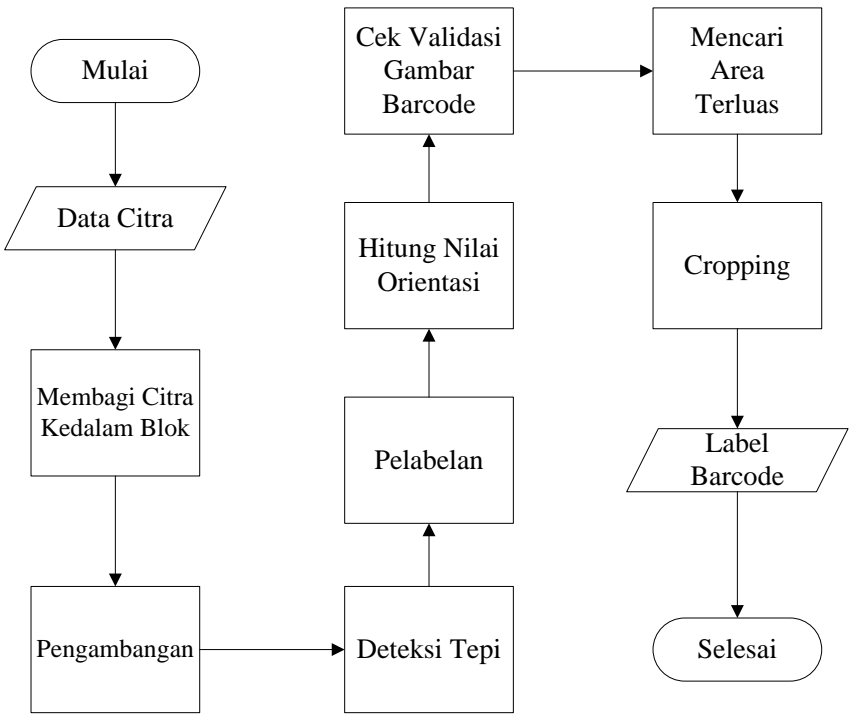

Gambar 6 Diagram alir proses locating barcode

\subsubsection{Scanline}

Proses scanline dilakukan untuk mengambil baris per baris dari data citra yang kemudian diproses untuk mengetahui apakah baris tersebut sesuai dengan syarat barcode atau tidak. Dengan cara ini diharapkan paling tidak terdapat satu baris yang sesuai dengan persyaratan barcode. Diagram alir proses scanline ditunjukkan pada Gambar 7.

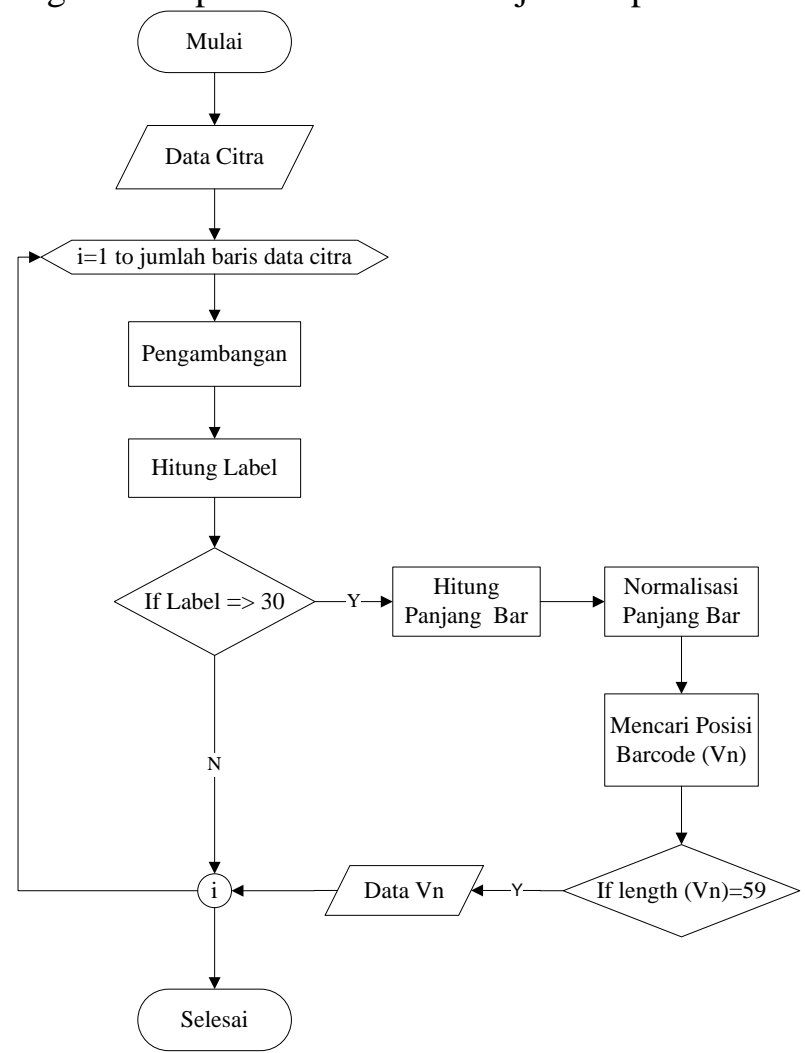

Gambar 7 Diagram alir proses scanline

Dalam proses scanline dilakukan proses perhitungan label. Sesuai dengan teori pengkodean barcode EAN-13 sebuah label barcode terdiri dari 30 bar hitam dan 29 bar putih. 
Oleh karena itu jumlah label dari setiap baris yang diambil dari gambar barcode yang baik (tidak memiliki noise) memiliki jumlah 30 label.

Namun karena citra yang diolah tidak selalu baik (tergantung dari hasil locating barcode) maka kemungkinan jumlah label yang dihitung pada setiap baris tidak sama dengan 30. Jika jumlah label lebih dari 30 dapat dipastikan baris tersebut masih memiliki noise atau derau. Sedangkan jika jumlah label kurang dari 30, bisa dipastikan bahwa baris tersebut bukan merupakan label barcode, kemungkinan lain adalah label barcode pada baris tersebut rusak (cacat). Berikut ini adalah ilustrasi hasil dari proses hitung label di beberapa kasus yang ditunjukkan melalui Gambar 8.

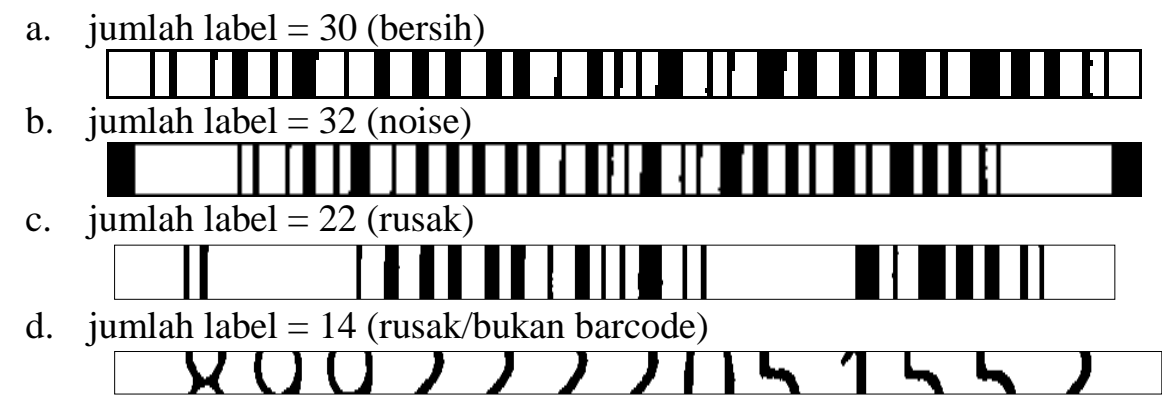

Gambar 8 Ilustrasi hasil proses hitung label

\subsubsection{Normalisasi}

Proses normalisasi berguna untuk melakukan rekonstruksi data vektor menjadi pola barcode yang utuh berdasarkan vektor penanda pada proses sebelumnya. Baris vektor yang sesuai dengan persyaratan barcode digunakan sebagai input dalam proses pengujian menggunakan metode LVQ (Learning Vector Quantization). Namun masih ada beberapa proses pengecekan yang harus dilakukan sebelum proses rekonstruksi tersebut.

\subsubsection{Identifikasi dengan $L V Q$}

Pada tahapan ini sistem akan melakukan identifikasi (pengujian) terhadap input berupa pola barcode yang diperoleh pada tahapan sebelumnya menggunakan metode LVQ (Learning Vector Quantization). Jaringan syaraf tiruan bertugas mengklasifikasikan input kedalam target/kelas dengan menyesuaikan nilai bobot dari masing-masing node-nya. Proses klasifikasi ini berdasarkan bobot tiap node yang telah dilatih sebelumnya sehingga pada proses klasifikasi tidak terjadi perubahan atau penyesuaian bobot.

Metode LVQ melakukan klasifikasi dengan mencari jarak antara bobot data uji dengan data acuan. Rumus untuk mencari jarak dalam metode LVQ ditunjukkan melalui rumus berikut ini :

$$
\text { Jarak }=\sqrt{ }\left(\mathrm{X}_{11}-\mathrm{W}_{11}\right)^{2}+\ldots+\left(\mathrm{X}_{\mathrm{ij}}-\mathrm{W}_{\mathrm{ni}}\right)^{2}
$$

Dengan menggunakan prinsip bahwa nilai paling kecil yang dihasilkan adalah pemenang dan merupakan kelas dari input tersebut maka pada lapisan keluaran (output layer) digunakan sebuah fungsi pembanding yang berguna membandingkan dua nilai tersebut. Pola barcode yang dilakukan pengujian menggunakan metode LVQ merupakan pola dari digit ke-2 sampai dengan digit ke-13 nilai barcode. Sedangkan digit pertama nilai barcode dapat ditentukan dari pola paritas sisi kiri barcode.

\subsubsection{Verifikasi}

Proses selanjutnya sebelum memperoleh nilai akhir dari label barcode adalah verifikasi, yaitu dengan cara menghitung nilai checksum. Checksum adalah digit ke-13 dari nilai barcode yang berguna untuk pengecekan nilai barcode yang dihasilkan. Setelah semua digit diterjemahkan, checksum dapat dihitung untuk memastikan bahwa nilai tersebut cocok dengan digit ke-13 dari nilai barcode. Sebuah ketidakcocokan akan berarti bahwa barcode itu tidak benar diterjemahkan.

IJCCS Vol. 7, No. 2, July 2013 : $121-132$ 


\section{HASIL DAN PEMBAHASAN}

Pembahasan mengenai kinerja sistem dilakukan dengan melihat hasil dari proses identifikasi, dimana dalam proses ini dilakukan identifikasi terhadap citra label barcode yang diperoleh dari kamera. Sehingga tingkat keberhasilan dapat diukur berdasarkan jumlah citra yang berhasil diidentifikasi oleh sistem dengan benar. Pada penelitian ini data citra yang digunakan adalah 72 citra. Pembahasan ini dibagi menjadi 2 bagian yaitu pembahasan mengenai kinerja dari proses locating barcode dan kinerja dari proses pengenalan pola menggunakan metode LVQ.

\subsection{Analisis Proses Locating Barcode}

Dalam analisis proses locating barcode dilakukan perbandingan dalam penggunaan ukuran blok untuk membagi data citra, yaitu antara ukuran blok 64x64 pixel dengan ukuran blok $32 \times 32$ pixel. Proses locating barcode disebut berhasil jika label barcode yang dihasilkan melalui proses ini adalah label barcode yang utuh, sedangkan proses locating barcode disebut gagal apabila proses ini tidak mendapatkan label barcode yang diinginkan, ataupun menghasilkan label barcode tetapi tidak secara utuh. Dari hasil analisis ini dapat diketahui ukuran blok yang lebih baik untuk digunakan dalam proses locating barcode. Perbandingan hasil proses locating barcode menggunakan blok ukuran 64x64 dengan blok ukuran 32x32 ditunjukkan pada Gambar 9.
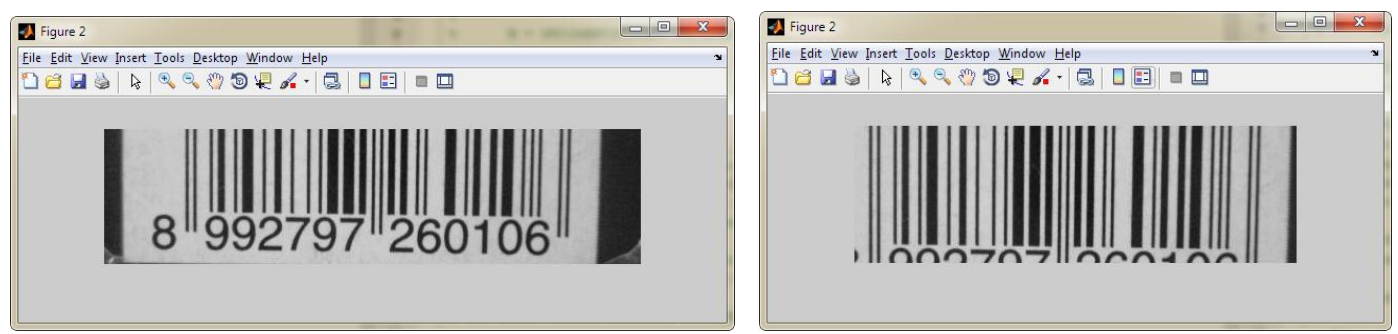

Gambar 9 Perbandingan hasil proses locating barcode

\subsubsection{Ukuran blok $64 x 64$}

Pengujian proses locating barcode dalam sub bab ini dilakukan terhadap 72 citra dengan menggunakan ukuran blok $64 \times 64$ pixel. Berdasarkan hasil pengujian proses locating barcode dengan ukuran blok 64x64 memiliki tingkat akurasi sebesar 47,2 \%. Dari 72 citra yang diuji hanya 34 citra yang berhasil melalui proses locating barcode dengan baik. Sementara waktu yang dibutuhkan untuk melakukan proses ini adalah sekitar 2-5 detik.

\subsubsection{Ukuran blok $32 \times 32$}

Pengujian proses locating barcode dalam sub bab ini dilakukan terhadap 72 citra dengan menggunakan ukuran blok 32x32 pixel. Berdasarkan hasil pengujian proses locating barcode dengan ukuran blok 32x32 memiliki tingkat akurasi sebesar 87,5\%. Dari 72 citra yang diuji diperoleh sebanyak 63 citra yang berhasil melalui proses locating barcode dengan baik. Sementara waktu yang dibutuhkan untuk melakukan proses ini adalah sekitar 5-8 detik. Perbandingan hasil penggunaan blok ukuran 64x64 dengan blok ukuran 32x32 ditunjukkan pada Gambar 10.

\subsection{Analisis Proses Identifikasi dengan Metode LVQ}

Proses identifikasi dilakukan dengan menggunakan metode LVQ seperti yang telah dibahas pada sub bab sebelumnya. Namun sebelum proses identifikasi harus dilakukan proses scanline dan proses normalisasi terlebih dahulu. Kedua proses ini merupakan serangkaian proses yang mendukung suksesnya proses identifikasi dengan metode LVQ. Hasil dari proses 
identifikasi berupa nilai barcode dari citra yang diberikan dan waktu yang digunakan untuk melakukan proses tersebut.

Dalam analisis proses identifikasi dilakukan pengujian terhadap 72 citra. Dari 72 citra tersebut dikenai proses locating barcode terlebih dahulu menggunakan blok dengan ukuran 32x32. Sehingga dari proses tersebut tersisa sebanyak 63 citra yang memungkinkan untuk dilakukan proses identifikasi. Proses pengujian dilakukan dengan cara membandingkan nilai barcode yang dihasilkan oleh sistem dengan nilai barcode yang sebenarnya. Sehingga melalui proses tersebut dapat diketahui kinerja sistem dan keterbatasan sistem dalam melakukan identifikasi barcode. Hasil proses identifikasi barcode ditunjukkan pada Gambar 11.
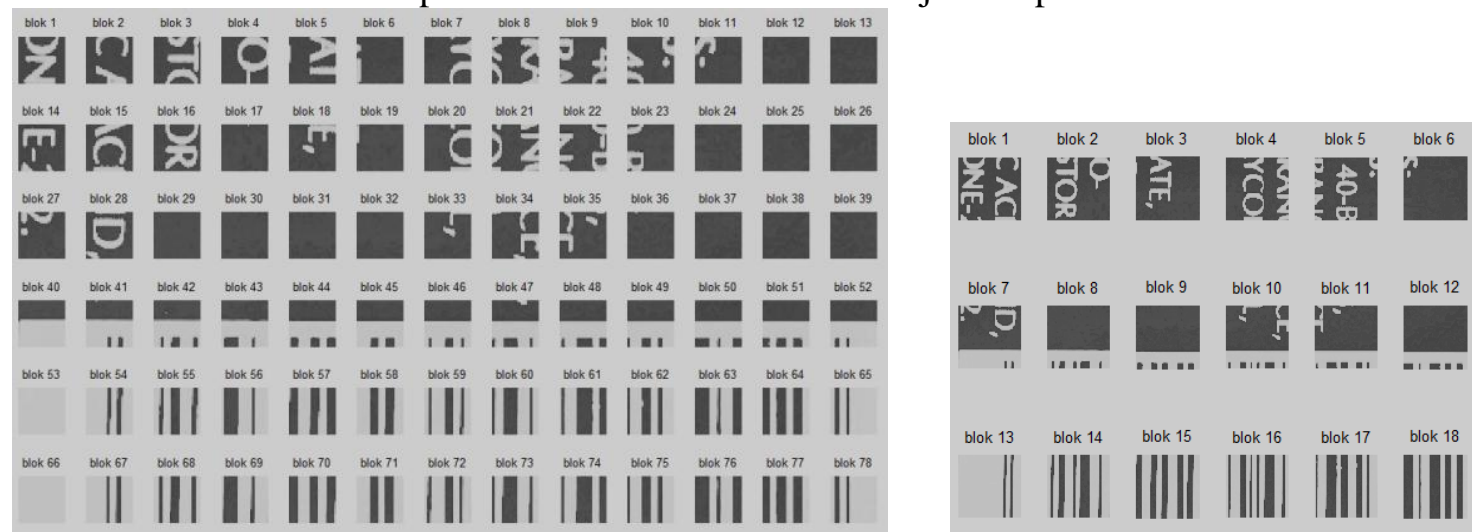

Gambar 10 Perbandingan blok ukuran 32x32 dengan blok ukuran 64x64

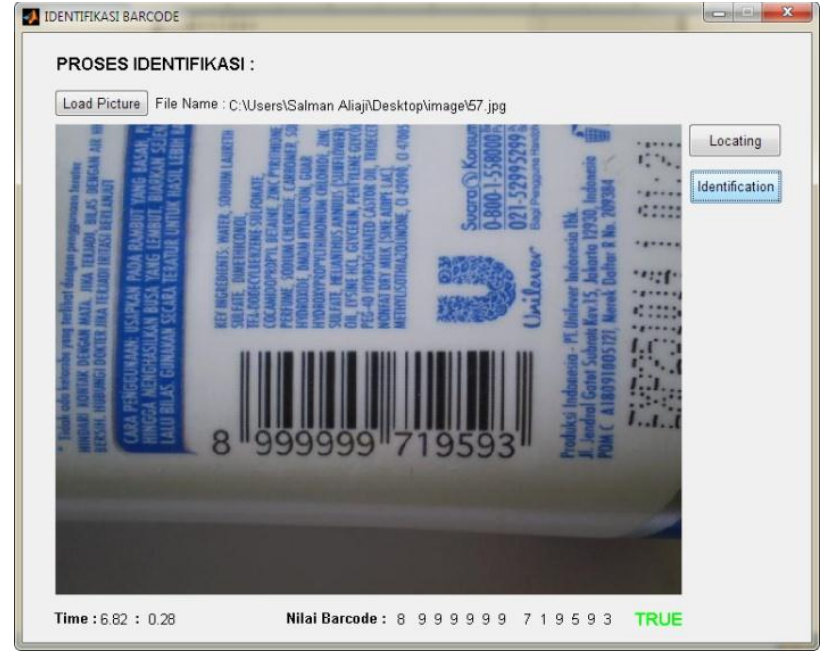

Gambar 11 Hasil proses identifikasi barcode

Berdasarkan hasil pengujian yang telah dilakukan proses identifikasi pola barcode menggunakan metode LVQ, scanline, dan normalisasi tersebut memiliki tingkat akurasi sebesar 73,6 \% dari 72 citra. Bila citra yang gagal dalam proses locating barcode tersebut diabaikan maka tingkat akurasi untuk proses identifikasi adalah sebesar 84,1\% dari 63 citra. Sementara waktu yang dibutuhkan untuk melakukan proses ini adalah sekitar 0.5 detik. Dataset yang diujikan juga dilakukan perbandingan dengan menggunakan alat pembaca barcode komersial mutakhir yang dibuat oleh DataSymbol (www.datasymbol.com). Hasil perbandingan dengan pembaca barcode komersial berbasis gambar tersebut ditunjukan pada Tabel 3.

Tabel 3 Perbandingan identifikasi barcode menggunakan scanner komersial

\begin{tabular}{|l|c|c|}
\hline \multicolumn{1}{|c|}{ Metode } & Berhasil Dikenali & Total Citra \\
\hline Metode yang diusulkan & 53 & 72 \\
\hline DataSymbol (scanner komersial) & 65 & 72 \\
\hline
\end{tabular}

IJCCS Vol. 7, No. 2, July 2013 : 121 - 132 
Perbandingan juga dilakukan dengan membandingkan metode yang diusulkan oleh peneliti sebelumnya dalam melakukan identifikasi barcode. Untuk melakukan perbandingan dan pengujian perlu menggunakan dataset yang disediakan oleh peneliti sebelumnya. Tiga buah penelitian sebelumnya yang dilakukan perbandingan adalah sebagai berikut:

1. Perbandingan dengan metode [8].

Chai dan Hock dalam tulisannnya tidak memberikan dataset, namun kami mengusulkan suatu perbaikan dalam proses locating barcode berdasarkan metode yang diusulkannnya. Chai dan Hock melakukan operasi morfologi untuk proses locating barcode dimana mereka menggunakan skeletonizing, sementara kami mengusulkan metode deteksi tepi yang lebih baik sesuai dengan metode penelitian yang kami usulkan. Hasil dari perbaikan tersebut memiliki perbedaan yang jelas sebagaimana ditunjukkan pada Gambar 12.

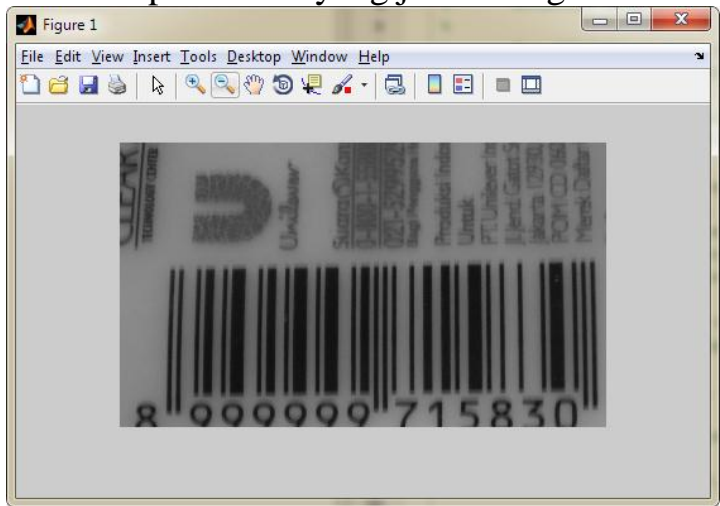

(a)

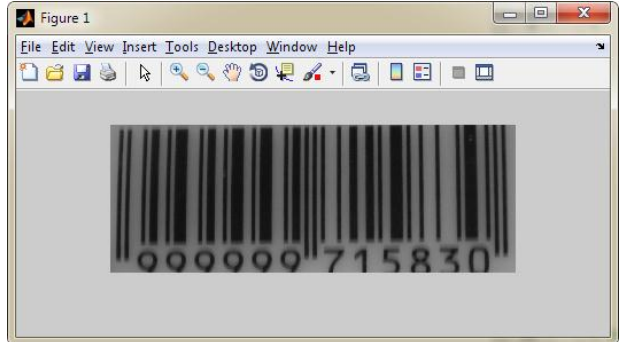

(b)

Gambar 12 Hasil perbandingan proses locating barcode (a) Metode Chai dan Hock

(b) Metode yang diusulkan

2. Perbandingan dengan [9].

Dataset yang juga digunakan oleh [9], tersebut dapat diperoleh di alamat http://cvpr.unimuenster.de/research/barcode. Dalam melakukan perbandingan digunakan foto label barcode yang berukuran 640x480 pixel. Dari 50 gambar yang dilakukan pengujian terdapat 31 gambar yang berhasil diidentifikasi dengan benar. Sehingga tingkat akurasi yang diperoleh sekitar $62 \%$. Sementara metode yang diusulkan oleh Wachenfeld, dkk memiliki tingkat akurasi sebesar 90,5\% pada gambar dengan resolusi 640x480 pixel.

3. Perbandingan dengan [10].

Dataset yang digunakan terdiri dari 44 gambar dalam berbagai resolusi, distorsi dan kontras yang dapat diunduh di http://www.ski.org/Rehab/Coughlan_lab/Barcode/. Mereka juga melakukan perbandingan dengan aplikasi pembaca barcode komersial mutakhir dari DataSymbol. Perbandingan hasil pengujian antara metode yang kami usulkan, metode Tekin dan Coughlan dan alat pembaca barcode komersial pada dataset yang sama ditunjukkan pada Tabel 4.

Tabel 4 Perbandingan identifikasi barcode pada dataset Tekin dan Coughlan

\begin{tabular}{|l|c|c|}
\hline \multicolumn{1}{|c|}{ Metode } & Berhasil Dikenali & Total Citra \\
\hline Metode yang diusulkan & 30 & 44 \\
\hline Tekin dan Coughlan (2009) & 42 & 44 \\
\hline DataSymbol (scanner komersial) & 39 & 44 \\
\hline
\end{tabular}

\section{KESIMPULAN}

Berdasarkan hasil-hasil yang diperoleh dalam penelitian ini, maka dapat disimpulkan:

1. Sistem yang dikembangkan telah mampu menemukan label barcode di dalam citra melalui proses locating barcode. Dari 72 citra yang diuji diperoleh tingkat akurasi adalah sebesar 
47,2 \% menggunakan blok dengan ukuran 64x64 pixel, sementara tingkat akurasi sebesar $87,5 \%$ diperoleh bila menggunakan blok dengan ukuran 32x32 pixel.

2. Metode Learning Vector Quantization (LVQ) dapat diimplementasikan dan mampu mengenali pola karakter barcode. Berdasarkan hasil pengujian, diperoleh tingkat akurasi sebesar $73,6 \%$ dari 72 citra yang diuji. Dari 72 citra terdapat 9 citra yang gagal dalam proses locating barcode, sehingga bila citra tersebut diabaikan maka tingkat akurasinya adalah sebesar $84,1 \%$ dari 63 citra.

\section{SARAN}

Beberapa saran untuk penelitian yang akan datang adalah sebagai berikut :

1. Proses akuisisi citra dalam pengembangan sistem ini masih dilakukan secara manual, dalam penelitian yang akan datang dapat dilakukan secara real time.

2. Sistem yang dibangun dalam penelitian ini dapat diimplementasikan di dalam komputer dan dengan memanfaatkan kamera digital, untuk penelitian selanjutnya sistem yang dibangun dapat diterapkan dalam perangkat mobile yang menggunakan kamera agar lebih fleksibel dan dapat digunakan oleh masyarakat luas.

3. Jenis barcode yang dikenali dalam sistem yang dibangun adalah jenis barcode satu dimensi dengan simbologi EAN-13, untuk penelitian selanjutnya diharapkan sistem dapat mengenali barcode 2 dimensi yang sudah mulai trend.

\section{DAFTAR PUSTAKA}

[1] Malik, J. J., Wijaya, R. dan Taufiq, R., 2010, Implementasi Teknologi Barcode Dalam Dunia Bisnis, Penerbit Andi, Yogyakarta.

[2] Janapriya, R., Kularatne, L., Pannipitiya, K., Gamakumara, A., Silva, C. dan Wickramarachchi, N., 2003, An Intelligent Algorithm for Utilizing a Low Cost Camera as an Inexpensive Barcode Reader, Proc. ${ }^{\text {st }}$ Annual Session (SLAAI), Colombo Sri Lanka, 16 September 2003.

[3] Ezekiel, S., Greenwood, G. dan Pazzaglia, D., 2004, Barcode Identification By Using Wavelet Based Energy, Proc Modelling Identification And Control, 109-112.

[4] Liyanage, J., 2007, Efficient Decoding of Blurred, Pitched, and Scratched Barcode Images, Second International Conference on Industrial and Information Systems (ICIIS 2007), University of Peradeniya, Sri Lanka, 8-11 Agustus 2007.

[5] Gallo, O. dan Manduchi, R., 2009, Reading Challenging Barcodes with Cameras, Proc IEEE Workshop Appl Comput Vision, 1-6.

[6] Leung, K.M., 2009, Learning Vector Quantization, http://cis.poly.edu/ mleung/CS6673/s09/LVQ.pdf, diakses tanggal 18 April 2012.

[7] Ghosh, A., Biehl, M. dan Hammer, B., 2006, Performance analysis of LVQ algorithms: a statistical physics approach, J. Neural Networks: Advances in Self Organising Maps, 6, 19, 817-829.

[8] Chai, D. dan Hock, F., 2005, Locating and Decoding EAN-13 Barcodes from Images Captured by Digital Cameras, 5th International Conference on Information Communications Signal Processing, Bangkok, 1595 - 1599.

[9] Wachenfeld, S., Terlunen, S. dan Jiang, X., 2008, Robust recognition of 1-D barcodes using camera phones, Proc. Pattern Recognition 19th International Conference, Tampa FL, 8-11 Desember 2008, 1-4.

[10] Tekin, E. dan Coughlan, J. M., 2009, A Bayesian Algorithm for Reading 1D Barcodes, Proc. Can. Conf. Computer Robot Vision, 61-67.

[11] Liao, H., Liu, S., Chen, L. dan Tyan, H., 1995, A Bar-code Recognition System Using Backpropagation Neural Networks, Engng. Applic. Artificial Intelligent, 1, 8, 81-90.

IJCCS Vol. 7, No. 2, July 2013 : $121-132$ 